\title{
Efficiency of Vegetable Marketing in Peri-Urban Areas of Ogun State, Nigeria
}

\author{
Samuel Uche Isitor ${ }^{1}$, Abiodun Olanrewaju Otunaiya $^{2} \&$ Joel Oluwaseyi Iyanda $^{1}$ \\ ${ }^{1}$ Department of Agricultural Economics and Extension, College of Agricultural Sciences, Landmark University, \\ Omu-Aran, Kwara State, Nigeria \\ ${ }^{2}$ Department of Agricultural Economics and Farm Management, College of Agricultural Sciences, Olabisi \\ Onabanjo University, Yewa Campus, Ayetoro, Ogun State, Nigeria \\ Correspondence: Samuel Uche Isitor, Department of Agricultural Economics and Extension, College of \\ Agricultural Sciences, Landmark University, Omu-Aran, Kwara State, Nigeria. E-mail: uisitor@hotmail.com
}

Received: December 21, 2015 Accepted: January 23, 2016 Online Published: February 15, 2016

doi:10.5539/jas.v8n3p142 URL: http://dx.doi.org/10.5539/jas.v8n3p142

\begin{abstract}
Against the backdrop evidenced in the substantial wastage, deterioration in quality, and frequent mismatch between demand and supply of vegetables spatially and overtime; this study examined the efficiency of vegetable marketing in Ifo and Ado-Odo L.G.As of Ogun State, Nigeria. Primary data were employed for the study. Data were collected from 120 respondents with the aid of structured questionnaire using multistage sampling procedure. Analytical tools used included, Descriptive statistics, budgetary and marketing efficiency analyses. The study revealed that women $(78.3 \%)$ were the major players in the enterprise and most had basic education with majority having business experience of more than five years. However, they relied on their personal savings to run their enterprise. Indigenous vegetable marketing was found to be profitable and efficient as indicated by the positive net margin of $\$ 29,180.05$. As an indication of the profit maximization motive of the marketers, various marketing efficiency scores were computed for the selected indigenous vegetables. The scores are $10.85 \%, 3.88 \%, 5.27 \%, 2.54 \%, 5.32 \%$, and $2.46 \%$ for ugu, tomato, okra, amaranthus, celocia and chocorus, respectively. It is recommended that extension trainings on preservation of indigenous vegetables should be conducted and accessible funds should be made available to these marketers, to forestall the problem of spoilage and lack of funds, as these constituted major drawbacks on marketing efficiency in the study areas.
\end{abstract}

Keywords: marketing efficiency, net margin, Ogun State, vegetables

\section{Introduction}

In sub-Saharan Africa, indigenous vegetables have been significant component of households' diet (Oluoch et al., 2009). They are of great nutritive value and are important sources of vitamins, minerals, proteins, carbohydrates and dietary fibers. Hence, vegetables are essential components of the human diet. It is often said that the nutritional security of a country can be achieved only when enough vegetables are consumed (Udoh \& Etim, 2006a). According to FAO (1998), vegetables refer to all categories of plants whose leaves, fruits or roots are acceptable and used as vegetables by urban and rural communities through custom, habit and tradition. There are a host of terms describing traditional African vegetables (TAV), including indigenous African vegetables (IAV); African indigenous vegetables (AIV) traditional leafy vegetables (TLV); African leafy vegetables (ALV); traditional African leafy vegetables (TALV or TLV) - and all are subject to contested meanings (Ambrose-Oji, 2009).

However, in Nigeria, some common indigenous vegetables include Ugu (Telfairia occidentalis), water leaf (Talinium triangulaire), bitter leaf (Vernonia amygdalina), Green (Amaranthus caudatus) and ukazi (Gnetum africanum) and examples of fruit vegetables are cucumber, garden egg, carrot, Cabbage, and onion. Vegetables are very essential for human consumption and must be available at all times in an adequate amount and quality. It must also be safe for consumption, and the price must be within the range of the consumers' budget (Firdaus \& Gunawan, 2012)

Indigenous vegetable production like any other farming activity utilizes resources. Udoh and Etim (2006a) opined that for optimum production, available resources must be utilized by farmers as efficiently as possible 
and as managers of land, they need to manage problems arising from deteriorating natural resources (Rosegrant et al., 2005; cited in Udoh \& Etim, 2006b). Also, it is noteworthy that information on the distribution and marketing of these vegetable species would be vital and could constitute the prop on which intervention on the development of the marketing system should be based (Agbugba et al., 2011). In the same vein, the fluctuations in the prices of vegetables could have negative impacts on the consumers, and also increase the possibility of farmers to experience loss, when the price information in the marketing chain does not reach them as at when needed. Thus, the linkage between producer and market is very important in order to increase farmers' income. For these reasons therefore, marketing efficiency is a very important goal. In recent years, there have also been great concerns regarding the efficiency of marketing of fruits and vegetables in Nigeria. This is evident in the substantial wastage, deterioration in quality, and frequent mismatch between demand and supply of vegetables spatially and over time.

It is believed that poor linkages in the marketing channels and poor marketing infrastructure are leading to high and fluctuating consumer prices, and only a small proportion of the consumers' money is reaching the vegetable farmers (Akinpelu \& Adenegan, 2011). Against this backdrop, this study was therefore carried out to describe the socioeconomic characteristics of vegetable marketers in the study area; identify the marketing channel of selected vegetables; determine the efficiency of vegetable marketing; and describe the constraints faced in vegetable marketing in the study area.

\subsection{Vegetable Marketing in Nigeria}

Vegetable marketing is one of the most rewarding and risky farming activities. Its special characteristics, high perishability and price and yield variations throughout a production year, coupled with the changing customers' demand could lead to increased uncertainty encountered by vegetable marketers (Vassalos, 2013). In the same vein, Adenuga et al. (2013) described marketing of vegetable as a complex phenomenon due to its perishable nature, seasonality and bulkiness. To mitigate this challenge, they argued that vegetable production requires an efficient marketing system. From their findings they prescribed the development of motor-able roads and efficient transport system, together with strengthening of vegetable farmers' cooperatives as factors that may enhance farmers' marketing efficiency in Kwara State, Nigeria.

Noteworthy is the fact that heavy losses are encountered in crop production. According to Ibeawuchi et al. (2015), no one knows exactly how much food is lost between harvest and consumption. The supplied figure for post-harvest loss estimates for fruits and vegetables are difficult to substantiate except on limited, controlled experimental basis. However, it is significant to mention that losses in fruits and vegetables between rural production and town consumption in the tropics are as high as 50\% (Oyeniran, 1988). These losses have been observed to occur during transportation, storage and marketing (Daramola, 1998).

Other established factors responsible for the damages and losses in fresh produce are; vibrations resulting from the transport vehicles as they navigate undulation and irregularities on the roads (Jones et al., 1991 cited in Ibebuchi et al., 2015). Another factor is attributed to the use of unsuitable packaging containers. To minimize these losses, they proffered that government should provide infrastructural facilities such as electricity and good roads since storage facilities require electricity to operate them. Also, in a related study, Oladapo et al. (2007) found that chief among factors that contributed to high marketing cost, is transportation cost followed by storage cost. Their findings were corroborated by Fafchamps and Minten (2001) who asserted that transport cost is important for the reduction of marketing cost.

\section{Methodology}

\subsection{The Study Area}

The study was conducted in Ifo and Ado-Odo/Otta Local Government Areas (LGAs) of Ogun State. Ifo L.G.A has a land area and population of 82,000 sq km and 524,837 inhabitants, respectively, the Local Government is predominantly made up of the people of Egba and Awori origin, and all other sub-ethnic groups co-existing in a peaceful atmosphere. While Ado-Odo L.G.A has a population of 526,565 (NPC, 2006), and a landmass of 1,460 square kilometres (Ogun State Government, 2012). Ado-Odo L.G.A consists mainly of the people of Awori, Yewa and Egba origin. Vegetable markets are predominant in both L.G.As.

\subsubsection{Sampling Procedure, Sample Size and Method of Data Collection}

Multistage sampling procedure was used to select vegetables marketers for this study. Ifo and Ado-Odo L.G.As were purposively selected for the study due to their peri-urban nature and closeness to Lagos metropolis. These factors make vegetables predominant in many markets in the study area. The study area was structured by quarters. All quarters in the Local Government Areas constitute potential sampling frame. There are 18 quarters 
in Ado Odo/Otta Local Government Area, while Ifo Local Government Area has 22 quarters. Half of the quarters in each Local Government Area were randomly selected. This therefore means that 9 quarters were selected from Ado Odo/Otta while 11 quarters were selected from Ifo Local Government Area. A total of six (6) vegetable marketers were interviewed in each of the quarter in the study area. This procedure gave a total of one hundred and twenty (120) vegetable marketers used in the study. Data were elicited from respondents using structured questionnaire as interview guide.

\subsection{Analytical Techniques}

\subsubsection{Descriptive Statistics}

Descriptive statistics was employed to describe the socioeconomic characteristics and the constraints associated with vegetable marketing in Ifo and Ado-Odo LGAs of Ogun State.

\subsubsection{Cost \& Return and Marketing Efficiency Analyses}

Performance of vegetable marketing systems was analyzed using cost and returns as well as marketing efficiency analyses. The net margin is expressed as:

$$
\text { Net Margin }(\mathrm{NM})=\text { Gross Margin }- \text { Total Fixed Cost }
$$

Marketing Efficiency (ME) analysis was further used to determine how effective price of indigenous vegetables reflect the cost incurred in the marketing system, i.e. the price that consumers pay for the indigenous vegetables delivered by the marketing system should adequately reflect all marketing costs (Zalkuwi et al., 2015). In a perfectly competitive economic environment, prices will definitely reflect all such cost (Olukosi et al., 2007). Following, Acharya and Agarwal (2001) cited in Adenuga et al. (2013); the 'corrected marketing efficiency measure' was adopted for this study. This method explicitly incorporates marketing loss in the existing marketing ratio, given by

Where,

$$
\mathrm{ME}=\frac{\mathrm{NPF}}{\mathrm{MC}+\mathrm{MM}+\mathrm{ML}} \times \frac{100}{1}
$$

$\mathrm{NPF}=$ Net price received by vegetable marketer;

$\mathrm{MC}=$ Total marketing cost;

$\mathrm{MM}=$ Total marketing margin, and

$\mathrm{ML}=$ Marketing loss.

\section{Results and Discussion}

\subsection{General Characteristics of Vegetable Marketers in Ifo and Ado-Odo LGAs}

Majority (32.5\%) of the vegetable marketers was between the age bracket of 31-40 years and women made up $78.3 \%$ of the surveyed marketers (Table 1). This result indicates that women were dominant in vegetable marketing in Ifo \& Ado-Odo LGAs. About $60 \%$ of the marketers were married and more than half had household size between 4 and 6 members. This may be due to the fact that marriage and having children or dependents supplied the needed assistants in the markets, which is characteristically what prevails in the rural areas of Nigeria (Iyanda et al., 2014).

Furthermore, $48.3 \%$ had secondary education and about 32\% had acquired primary education (Table 2). According to Iyanda et al. (2014), having basic primary education is a resource that could enable these vegetable marketers to relate within and around their social system, aiding access to productive resources like credit and information on prices of vegetables. On the other hand, business experience of the marketers revealed that most of them have been doing business between 5 and 10 years, and more often than not they used their personal savings in running their vegetable enterprise. This result is in consonance with the findings in Iyanda et al. (2014). They reported that savings is seen as a self-insurance mechanism. In the same vein, Latortue and Goronja (2002) opined that the poor often prefer to save and are even willing to pay to do so, and savings may in fact be more important than credit in helping the poor to raise incomes and reduce risk. 
Table 1. Selected socioeconomic characteristics of Vegetable Marketers in Ifo \& Ado-Odo LGAs

\begin{tabular}{lll}
\hline Characteristic & Frequency & Percentage \\
\hline Age(years) & 31 & 25.8 \\
Below 30 years & 39 & 32.5 \\
31-40 years & 37 & 30.8 \\
$41-50$ years & 12 & 10 \\
51-60 years & 1 & 0.8 \\
Above 60 years & & \\
Gender & 26 & 21.7 \\
Male & 94 & 78.3 \\
Female & & \\
Marital status & 19 & 15.8 \\
Single & 72 & 60 \\
Married & 4 & 3.3 \\
Divorced & 8 & 6.7 \\
Separated & 17 & 14.2 \\
Widowed & & \\
\hline
\end{tabular}

Note. Source: Field Survey, 2015.

Table 2. Selected socioeconomic characteristics of Vegetable Marketers in Ifo \& Ado-Odo LGAs

\begin{tabular}{|c|c|c|}
\hline Characteristic & Frequency & Percentage \\
\hline \multicolumn{3}{|l|}{ Education (Years) } \\
\hline No formal education & 18 & 15 \\
\hline Primary & 38 & 31.7 \\
\hline Secondary & 58 & 48.3 \\
\hline Tertiary & 6 & 5 \\
\hline \multicolumn{3}{|l|}{ Household size } \\
\hline $1-3$ & 18 & 15 \\
\hline $4-6$ & 70 & 58.3 \\
\hline $7-9$ & 25 & 20.8 \\
\hline $10-12$ & 6 & 5 \\
\hline Above 12 & 1 & 0.8 \\
\hline \multicolumn{3}{|l|}{ Credit source } \\
\hline Personal savings & 91 & 75.8 \\
\hline Gift/loan from friends \& relatives & 13 & 10.8 \\
\hline Loan from money lender & 7 & 5.8 \\
\hline loan from cooperative society & 9 & 7.5 \\
\hline \multicolumn{3}{|l|}{ Business experience } \\
\hline Below 5 years & 28 & 23.3 \\
\hline $5-10$ years & 36 & 30 \\
\hline $11-15$ years & 31 & 25.8 \\
\hline $16-20$ years & 15 & 12.5 \\
\hline Above 20 years & 10 & 8.4 \\
\hline
\end{tabular}

Note. Source: Field Survey, 2015. 


\subsection{Analysis of the Channels and Agencies involved in Vegetable Marketing}

Marketing channel is the sequence of intermediaries or middlemen, and markets through which produce pass from producers to final consumers. Olukosi et al. (2007) defined marketing agencies as the middlemen involved in carrying out marketing functions. They could be individuals or agribusiness organizations that specialize in performing the various marketing functions involved in the purchase or sale of agricultural commodities as they move from producers to consumers. Figure 1 shows that three main vegetable marketing channels were identified in the study area. They are namely:

Marketing Channel (1): Farmers - wholesalers - retailers - consumers;

Marketing Channel (2): Farmers - itinerant buyers - retailers - consumers;

Marketing Channel (3): Farmers - itinerant buyers - wholesalers - retailers - consumers.

Three sets of middlemen were identified in the vegetable marketing system in the study area, these are: Itinerant Buyers: They buy vegetables from the producers and later sell to the wholesalers or retailers; Wholesalers: These are merchants who buy vegetables in large quantities. They purchase directly from the farmers or itinerant buyers and they have storage and preservation facilities to hold large quantities of vegetables, they sell mainly to the retailers; and

Retailers: They are the middlemen who purchase from the wholesalers and itinerant buyers and sell directly to the consumers.

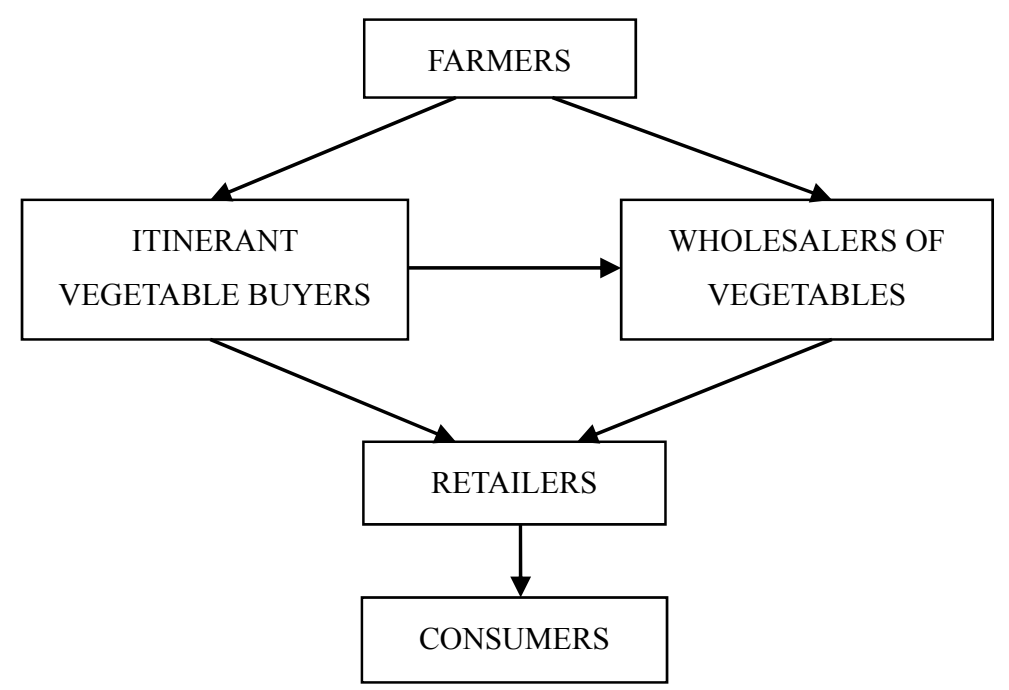

Figure 1. Marketing channel of vegetable in Ifo \& Ado-Odo LGAs

Note. Source: Field Survey, 2013.

\subsection{Market Place for Vegetables in Ifo \& Ado-Odo LGAs}

A market place refers to a particular geographical location where buyers and sellers meet periodically to transact their business (Kohls, 1961). The result in this study revealed that most of the transactions in vegetable marketing in the study area took place in the retail market (Figure 2). 


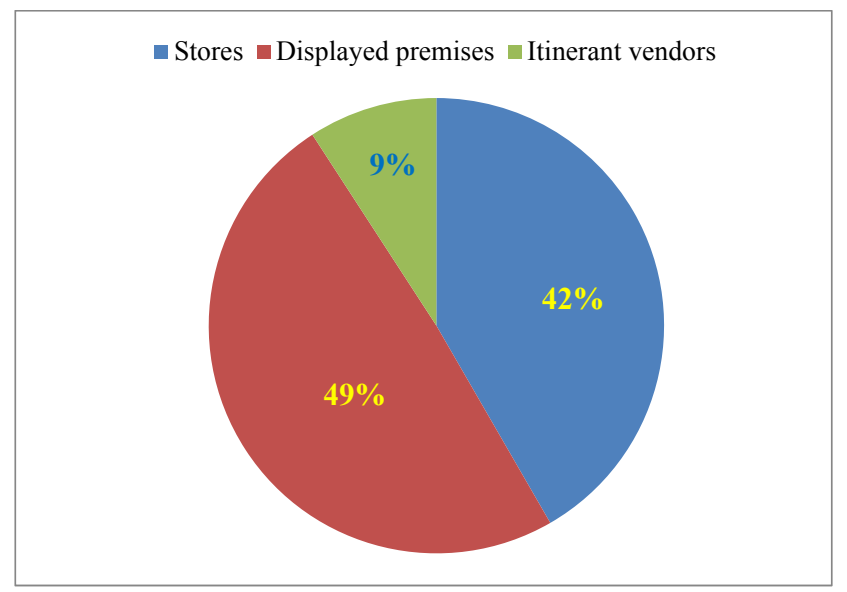

Figure 2. Distribution of vegetable marketers by market place

Note. Source: Field Survey, 2015.

\subsection{Gross Margin Analysis of Vegetable Marketing}

The estimated parameters and the relevant Gross Margin Analysis results obtained from the analysis are presented in Table 3. The analysis revealed that the Average Total Variable Cost stood at $\$ 206,496$ while the Average Total Fixed Cost was $\$ 16,657.45$, making a Total Cost of $\$ 223,153.45$ and a Total Revenue of 252,333.50.

The Gross Margin was therefore estimated to be $\$ 45,837.50$. i.e. Average Total Revenue less Average Total Variable Cost ( $\$ 252,333.50-\$ 206,496.00)$.

The Net Margin was $\$ 29,180.05$ i.e. Gross Margin less Average Total Fixed Cost (\$45,837.50 - 16657.45$)$.

Table 3. Result of budgetary analysis

\begin{tabular}{ll}
\hline Variables & Mean value (\$) \\
\hline REVENUE & $252,333.50$ \\
TVC & $206,496.00$ \\
TFC & $16,657.45$ \\
GM & $45,837.50$ \\
NM & $29,180.05$ \\
\hline
\end{tabular}

Note. Source: Field Survey, 2015.

\subsection{Marketing Efficiency of Selected Vegetables in Ifo and Ado-Odo LGAs}

Marketing efficiency was estimated by accounting for the marketing costs plus marketing losses of selected vegetables as presented in Table4. It is clear from the results that farm spoilage of vegetables had effect on the marketing efficiency of vegetable marketers. Marketers' net returns were higher when estimated without accounting for marketing losses. This indicated that their returns could be improved if proper measures were taken to prevent these losses.

Table 4. Marketing efficiency of selected vegetables in Ifo and Ado-Odo L.G.As

\begin{tabular}{lllllll}
\hline Marketing efficiency & Fluted Pumpkin & Tomato & Okra & Amaranthus & Celocia & Cochorous \\
\hline Net price received by farmer(\#/100kg) & 3928 & 3410 & 1223 & 1044 & 1305 & 1102 \\
Marketing cost(N/100kg) & 362 & 362 & 232 & 232 & 245 & 245 \\
Marketing loss ( $/ 100 \mathrm{~kg})$ & 0 & 518 & 0 & 179 & 0 & 203 \\
Marketing efficiency & 10.85 & 3.88 & 5.27 & 2.54 & 5.32 & 2.46 \\
\hline
\end{tabular}

Note. Source: Field Survey, 2015. 
The result of the analysis in Table 4 shows that fluted pumpkin has a marketing efficiency of 10.85, Tomato 3.88, Okra 5.27, Amaranthus 2.54, Celocia 5.32, and Chocorous 2.46. The Marketing Efficiency scores indicate that the marketing system of local vegetables in Ifo and Ado-Odo LGAs are efficient with that of fluted pumpkin being more efficient than the other vegetables. This result is colloborated by Adenuga et al. (2013), who obtained a Marketing Efficiency value of 10.85 for tomato, 5.27 for Okora, 5.32 for Amaranthus and 5.24 for Chochorus in a study of efficiency of the marketing of selected vegetables in Kwara State, Nigeria. In a related study of the economic potentials of fish marketing in Ogun State, Nigeria, Babalola et al. (2015) obtained a Marketing Efficiency score of 1.13, indicating that the market is efficient irrespective of the associated costs. Amao et al. (2011) applied Marketing Efficiency scores in analyzing the efficiency of pineapple marketing system in Edo and Delta states, Nigeria. The study obtained a M. E. score of 1.33 and concluded that since it was greater than 1, the marketing system was adjudged to be efficient. The result was also in consonance with Adesope et al. (2009) and Eze and Orebiyi (2005) that obtained M.E score of 1.17 and 1.70, respectively in their studies and concluded that the marketing system was efficient and profitable.

\subsection{Constraints Associated with Vegetable Marketing in Ifo \& Ado-Odo LGAs}

On examining the constraints associated with vegetable marketing, the study revealed (Table 5) that vegetable spoilage, bad road networks and inadequate access to capital topped reasons attributed to be the constraints encountered by vegetable marketers in Ogun State.

Table 5. Constraints associated with vegetable marketing in Ogun State

\begin{tabular}{lll}
\hline Constraints & Frequency & Percentage \\
\hline Use of crude implement & 10.0 & 8.3 \\
Bad road networks & 19.0 & 15.8 \\
High cost of vegetable seeds & 6.0 & 5.0 \\
Inadequate capital & 14.0 & 11.7 \\
Lack of adequate preservation method & 10.0 & 8.3 \\
Land tenure problem & 2.0 & 1.7 \\
Little or no assistance from government & 2.0 & 1.7 \\
Poor market structure \& communication & 10.0 & 8.3 \\
Spoilage problem & 44.0 & 36.7 \\
Climatic factors & 3.0 & 2.5 \\
Total & 120 & 100 \\
\hline
\end{tabular}

Note. Source: Field Survey, 2013.

\section{Conclusions and Recommendation}

The study examined the efficiency of vegetable marketing in Ifo and Ado-Odo L.G.As of Ogun State, Nigeria. Primary data were employed for the study. Data were collected from 120 respondents with the aid of structured questionnaire using purposive and simple random sampling techniques. Analytical tools used included, descriptive statistics, budgetary analysis and marketing efficiency. The study revealed that women $(78.3 \%)$ were the major players in the enterprise and most had basic education with majority having business experience of more than five years. However, they relied on their personal savings to run their enterprise. Indigenous vegetable marketing was found to be profitable and efficient as illustrated by the positive net return of $\$ 29,180.05$. As an indication of the profit maximization motive of the marketers, marketing efficiency scores were computed for the selected indigenous vegetables. The scores are $10.85 \%, 3.88 \%, 5.27 \%, 2.54 \%, 5.32 \%$, and $2.46 \%$ for fluted pumpkin, tomato, okra, amaranthus, celocia and chocorus, respectively. These scores show that the marketing of the selected indigenous vegetables are efficient since they are greater than 1, and the marketing of fluted pumpkin, with a Marketing Efficiency score of $10.85 \%$ being more efficient. It is recommended that extension trainings on preservation of indigenous vegetables should be conducted and accessible funds should be made available to these marketers, to forestall the problem of spoilage and inadequate access to capital, as these constituted major drawbacks on marketing efficiency in the study areas. 


\section{References}

Adenuga, A. H., Fakayode, S. B., \& Adewole, R. A. (2013). Marketing Efficiency and Determinants of Marketing Surplus in Vegetable Production in Kwara State. An invited paper presented at the 4th International Conference of the African Association of Agricultural Economists, September 22-25, Hammamet, Tunisia.

Adesope, A. A. A., Awoyinka, Y. A., \& Babalola, D. A. (2009). Economic Analysis of Group Marketing of Pineapple in selected markets of Osun State, Nigeria, acta Satech. Journal of Life and Physical Sciences, $3(1), 47-52$.

Agbugba, I. K., Okechukwu, F. O., \& Rifkatu, J. F. (2011). Challenges and Strategies for Improving the Marketing of Indigenous Leafy Vegetables in Nigeria. JHER, 14, 319- 331

Amao, I. O., Adebisi-Adelani, O., Olajide-Taiwo, F. B., Adeoye, I. B., Baimore, K. M., \& Olabode, I. (2011). Economic Analysis of Pineapple Marketing in Edo and Delta States, Nigeria. Libian Agriculture Research Center Journal International, 2(5), 205-208.

Ambrose-Oji, B. (2009). Urban Food Systems and African Indigenous Vegetables: Defining the Spaces and Places for African Indigenous Vegetables in Urban and Peri-Urban Agriculture. In C. M. Shackleton, M. Pasquini, \& A. W. Drescher (Eds.), African indigenous vegetables in urban agriculture (pp. 1-33). London: Earthscan.

Babalola, D. A., Bajimi, O., \& Isitor, S. U. (2015). Economic Potentials of Fish Marketing and Women Empowerment in Nigeria: Evidence from Ogun State, Nigeria. African Journal of Food, Agriculture and Nutrition and Development, 15(2), 9922-9934.

Daramola, A. M. (1998). Postharvest handling of indigenous fruits and vegetables: status, problems and prospects. Paper presented at the Meeting of Experts on Indigenous Crops and Animal Research and Development, Nigeria.

Eze, C. C., \& Orebiyi. (2005). Profitability of Pineapple Marketing in Owerri, Imo State, Nigeria. Journal of Agriculture and Food Science, 3(2), 151-157.

Fafchamps, M., \& Minten, B. (2001). Social capital and Agricultural trade. American Journal of Agricultural Economics, 2, 12-20. http://dx.doi.org/10.1111/0002-9092.00190

FAO (United Nations Food and Agriculture Organization). (1998). Traditional Food Plants, Food and Nutrition Paper 42. FAO, Rome, Italy.

Firdaus, M., \& Gunawan, I. (2012). Integration among Regional Vegetable Markets in Indonesia. J. ISSAAS, 18(2), 96-106.

Ibeawuchi, I. I., Okoli, N. A., Alagba, R. A., Ofor, M. O., Emma-Okafor, L. C., Peter-Onoh, C. A., \& Obiefuna, J. C. (2015). Fruit and Vegetable Crop Production in Nigeria: The gains, challenges and the way forward. Journal of Biology, Agriculture and Healthcare, 5(2), 194-208.

Iyanda, J. O., Afolami, C. A., Obayelu, A. E., \& Ladebo, O. J. (2014). Social capital and Access to Credit among Cassava Farming Households in Ogun State, Nigeria. Journal of Agriculture and Environmental Sciences, 3(2), 175-196. http://dx.doi.org/10.15640/jaes

Kohls, R. L. (1961). Marketing of Agricultural Products (3rd ed.). Collier-Macmillan Limited, London.

Latortue, A., \& Goronja, N. (2002). Helping to improve donor effectiveness in microfinance savings are as Important as credit: Deposit services for the poor consultative group to Assist the Poorest. DONOR BRIEF No. 4. Retrieved from https://www.cgap.org/sites/default/files/CGAP-Donor-Brief-Savings-Are-as-Importa nt-as-Credit-Deposit-Services-for-the-Poor-Jun-2002.pdf

National Population Commission (NPC). (2006). Population Distribution by Age and Sex (State and Local Government Area). Priority Table (Vol. IV, p. 263).

Oladapo, M. O., Momoh, S., Yusuf, S., \& Awoyinka, Y. (2007). Marketing margin and spatial pricing efficiency of Pineapple in Nigeria. Asian Journal of Marketing, 1(1), 12-22.

Olukosi, J. O., Isitor, S. U., \& Ode, M. O. (2007). Introduction to Agricultural Marketing and Prices: Principle and Applications (3rd ed., pp. 47-59). GU Publication.

Oluoch, M. O., Pichop, G. N., Sihie, D., Abukutsa-Onyango, M. O., Diouf, M., \& Shackleton, C. M. (2009). Production and Harvesting Systems for African Indigenous Vegetables. In C. M. Shackleton, M. W. 
Pasquini, \& A. W. Drescher (Eds.), African Indigenous Vegetables in Urban Agriculture (pp. 145-146). Earthscan, London.

Oyeniran, J. O. (1988). Report of the nationally coordinated research project on fruits and vegetables in Nigeria. Proc. Nat. Workshop on Improved Packaging and Storage Systems for Fruits and Vegetables in Nigeria. Ilorin, Nigeria.

Udoh, E. J., \& Etim, N. A. (2006a). Estimating Technical Efficiency of Waterleaf Production in a Tropical Region. International Journal of Vegetable Science, 12(3), 5-13.

Udoh, E. J., \& Etim, N. A. (2006b). Cocoyam Farms in Akwa Ibom State, Nigeria: A Stochastic Production Approach. Journal of Sustainable Development in Agriculture and Environment, 2, 41-48.

Vassalos, M. (2013). Essays on fresh vegetable production and marketing practices. A Dissertation submitted in partial fulfillment of the requirements for the degree of Doctor of Philosophy in the College of Agriculture at the University of Kentucky, Lexington, Kentucky.

Zalkuwi, J., Singh, U. P., Maurya, A., \& Ibrahim, A. (2015). Cost and Return Analysis of Local Chicken Marketing in Mubi North Local Government Area of Adamawa State, Nigeria. International Journal of Environmental \& Agriculture Research, 1(3), 5-8.

\section{Copyrights}

Copyright for this article is retained by the author(s), with first publication rights granted to the journal.

This is an open-access article distributed under the terms and conditions of the Creative Commons Attribution license (http://creativecommons.org/licenses/by/3.0/). 